\section{Geographic Concentration of Companies and Relationship Resources at the Horizontal Level}

\author{
Vinicius Farias Moreira ${ }^{1}$ \\ ${ }^{\mathbf{1}}$ Federal University of Campina Grande, Postgraduate Program in \\ Management, Campina Grande, Paraiba, Brazil \\ Walter Fernando Araújo de Moraes ${ }^{2}$ \\ ${ }^{2}$ Federal University of Pernambuco, Postgraduate Program in \\ Management, Recife, Pernambuco, Brazil \\ Jose Luis Hervas-Oliver ${ }^{3}$ \\ ${ }^{3}$ ESIC Business \& Marketing School, Madrid, Spain \\ Universitat Politecnica de Valencia, Valencia, Spain \\ Universidad De la Costa, Barranquilla, Colombia \\ Samuely Bezerra Barbosa Laurentino ${ }^{4}$ \\ ${ }^{4}$ University of São Paulo, Departament of Economics, Business \\ and Accounting, São Paulo, Brazil
}

Received on

$12 / 30 / 2017$

Approved on

$01 / 16 / 2019$

\section{Responsible editor:}

Prof. Dr. João Maurício Gama

Boaventura

\section{Evaluation process:}

Double Blind Review

\begin{abstract}
Purpose - This paper analyzes how horizontal relationship resources collaborated in the value creation process of fruit producing and exporting companies geographically concentrated in the São Francisco River Valley (SFRV), Brazil.

Design/methodology/approach - It is a qualitative case study, in which the units of analysis were the medium and large producing and exporting companies and the fruit cluster of the SFRV, understanding that both co-evolve. Semi-structured interviews were conducted with corporate, institutional, and support industry companies; there was also an analysis of secondary data using public and private documents. Content analysis was performed with the Atlas.ti software, which allowed a greater systematization of the findings.

Findings - The results revealed particular patterns of collaboration that indicate conditions and contributions derived from the links established among firms within the cluster, highlighting companies' strategies to create value. Significant volumes of demand, especially involving the international market, bring companies closer in terms of production protocols and joint business practices. These aspects favor collaboration in an essentially competitive environment. Participation in a cluster environment enhances cooperation ties by providing access to knowledge spillovers and, consequently, improving individual and collective competitiveness.
\end{abstract}

Originality/value - The study provides advances in the knowledge in the area by considering the microeconomic level of the firm in the cluster, and it also expands the empirical evidence on organizational relationships by presenting a study of a Brazilian agricultural cluster.

Keywords - Cooperative strategy; Business networks; Cluster; Atlas.ti.

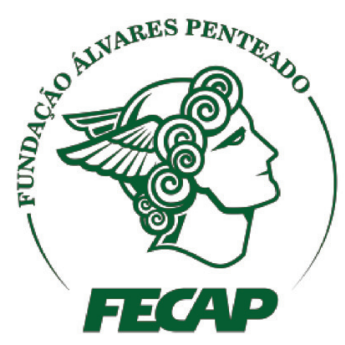

Review of Business Management

DOI: $10.7819 /$ rbgn.v21i4.4013 


\section{Introduction}

The cluster as an option for a regional economic development strategy can be found in different types of industries, present in developed and developing countries, in small and large economies, in rural and urban areas, and at different geographic levels, such as nations, states, metropolitan regions, or even cities (Eisingerich, Bell, \& Tracey, 2010; Porter, 2000).

The terms used to analyze the advantages of a locality are diverse, such as industrial districts, industrial clusters, industrial agglomerations, local productive and innovative arrangements, localized production systems, technological districts, etc. (Giuliani \& Bell, 2005; Lastres, Cassiolato, \& Campos, 2006; Malmberg \& Maskell, 2002; Porter, 1998). In any case, it is important to recognize that such agglomerations have been popularized in the specific literature as clusters, highlighting their importance in the national and international context for job generation, economic growth, technological development, and export potential (Suzigan, Garcia, \& Furtado, 2005).

In this paper, the concept of cluster established by Michael Porter was used as a reference. This author introduced it to Strategic Management (Lazzeretti, Sedita, \& Caloffi, 2013) and has been a reference for public policy academics and developers (Martin \& Sunley, 2003; McCann \& Folta, 2008). In seeking to identify the competitive advantage of countries, Porter (1991) ended up highlighting the existence of clusters as propellers of superior performance, independent of the performance of the countries. A cluster is understood as a group that is geographically close to interconnected companies and associated institutions in a particular field, bound by common and complementary interests (Porter, 2000).

A cluster is usually defined based on the horizontal dimension in which many companies operate in the same industry, i.e. produce a similar final product (Malmberg \& Maskell, 2002). Within it, interconnected companies have additional advantages such as easy access to specialized suppliers of raw materials and equipment, facilitated channels for customers, service providers, related industry companies, and associated institutions (universities, support agencies, and commercial associations, for example), while competing and cooperating with each other (Giuliani, 2013; Molina-Morales \& Martinez-Fernandez, 2004; Porter, 1998; 2000).

It is assumed that the development of a cluster and its companies are directly related, happening simultaneously, and hence separate and isolated analysis of either of these levels is insufficient to understand the process of value creation (Ter Wal, 2013). In this sense, and considering the literature on cooperative relationships, this paper seeks to know: In what way does cluster participation enable firms to create superior conditions through relationships between firms? The paper aims to offer new insights on how to identify the value creation process through the relationships between companies of the same cluster, based on the evidence from an important agricultural cluster in Brazil. According to Chim-Miki and BatistaCanino (2017), organizations that compete and cooperate, in so-called coopetition, compete for the overall benefits of their transactions and not only for market share. The process of value creation in inter-organizational cooperations is the phenomenon this paper focuses on.

The empirical field is the fruit-growing cluster of the San Francisco River Valley and its mango and table grape exporting companies. According to data from the Brazilian Ministry of Development Industry, and Foreign Trade (MDIC), mango and table grape exports are quite representative in fruit exports, and the São Francisco River Valley (SFRV) accounts for about $90 \%$ of the volume exported. The fruit cultivation practiced in the northeastern semi-arid region, using modern irrigated agriculture techniques, allows fruit production to occur throughout the year, and is an important factor of national development. 
This study aims to analyze how horizontal relationship resources collaborated in the value creation process of fruit producing and exporting companies geographically concentrated in the São Francisco River Valley. The study makes advances in the knowledge of the area by considering the microeconomic level of the firm in the cluster, which has received less attention among mainstream cluster studies (Giuliani, 2013, Hervas-Oliver, Albors-Garrigos, Miguel, \& Hidalgo, 2012; Rigby \& Brown, 2015), also highlighting the strategies of companies used to create value through their relationships with other companies in the cluster.

In addition to the Introduction, this paper includes a topic on the Theoretical Basis, presenting the central pillars that give rise to the benefits of relationships between companies; the Methodological Aspects, which indicate the criteria and conducts used for the research; the Results and Discussion, highlighted in the section entitled Horizontal Relationship Resources of the San Francisco River Valley; and finally, the Conclusions.

\section{Theoretical Basis}

Local resources are those intangible resources and capacities shared by companies within the same cluster, and suggest the application of the same logic geared towards achieving a sustainable competitive advantage (Barney, 1991), making it hard for companies outside the cluster to understand. This type of knowledge is based on routines related to the history of the companies, business practices, specific institutions, and multiple links between the actors (Molina-Morales \& Martinez-Fernandez, 2004). This perspective is strongly influenced by the Knowledge-Based View (KBV), which emphasizes the interactions and knowledge exchanges between the cluster companies and the knowledge creation capacities of the cluster (Arikan, 2009; Malmberg \& Maskell, 2002; Tallman, Jenkins, Henry \& Pinch., 2004). This involves an additional understanding of the sustainability of competitive advantage for clusters and for companies within them, subsidizing the understanding of the resources of the locality (Hervas-Oliver \& Albors-Garrigós, 2007; Tallman et al, 2004). This flow of knowledge circulating in a cluster (knowledge spillovers) enables companies located in this geographic space to introduce innovations faster than others located outside it (Bahlmann \& Huysman, 2008).

Local rivalry is an aspect that allows companies to structure and strengthen themselves against international rivals and competition from big players. Furthermore, its dynamics fuel all other aspects of the cluster's structure (Verschoore, Wegner, \& Balestrin, 2015). It is supposed that in cases where companies within a cluster are in vigorous competition with each other, the logic of spatial organization may fail (McCann \& Folta, 2008; Porter, 1998). The cooperation is based on the fact that each individual company would have to overcome great obstacles to gain access to the opportunities when compared to joint action. Companies in a cluster use different network types to access the knowledge of local and more distant actors (Giuliani, 2013). Knowledge and learning are social and territorial processes, therefore local resources in which the personal contact is fostered by geographical proximity and there is a concentration of economic activity are key elements in the transfer of knowledge (Bahlmann \& Huysman, 2008). Among local actors, horizontal relationship resources, such as those developed and shared by companies producing similar goods and competing with each other in the cluster environment, are generally highlighted and have a positive influence on their international competitiveness (Giuliani, 2013; Porter, 1998; Ter Wal, 2013; Zen, Fensterseifer, \& Prévot, 2014).

The relational view is explored by Dyer and Singh (1998), who indicate that cooperation between companies aims to establish value creation links between them, which can be critical resources in the search for competitive advantage in environments where companies maintain multiple and frequent relationships. 
For Dyer and Singh (1998), relational resources are protected by mechanisms aimed at preserving their promised returns, notably: a) the causal ambiguity of these resources; b) the discomfort of temporal compressibility, indicating that even if the competitors understand what generates the returns, they can not be quickly replicated; c) the possibility that the assets present in the interconnectivity currently require values that no longer invite to imitation and whose roots were planted in a previous period; d) the difficulty of finding partners with strategic resources complementary to the relational capacity; e) the possibility that the capabilities of a potential partner are indivisible or inaccessible (for example, due to its relationship with other companies); and, finally, f) it may be that the institutional environment is socially complex, involving the existence of formal rules (legal controls) or informal rules (social controls) that combat opportunism and encourage cooperative behavior. These mechanisms are basically the same as those applied to the difficulty of imitating strategic business resources (Barney, 1991; Dierickx \& Cool, 1989).

Competition will coexist with cooperation because they occur in different dimensions and between different players, generating a mutual gain. This hybrid of competitive cooperation, recognized as coopetition (Brandenburger \& Nalebuff, 1996; Chim-Miki \& Batista-Canino, 2017), is the expected behavior within a cluster, leading to strategic management based on coopetition, i.e. managing the inherent tensions of these relationships, and becoming a key to the cluster's success, for it allows for cost savings and stimulates innovation (Bengtsson, Raza-Ullah, \& Vanyushyn, 2016; Chim-Miki \& Batista-Canino, 2017).

Cluster members have privileged access to specialized information about the market, technical issues, and competitive information gathered within the cluster, as well as gains in personal relationships and community links that inspire confidence among the various agents that facilitate the flow of information (Malmberg \& Maskell, 2010). As indicated, these horizontal relationships generate valuable knowledge exchange and enable interactive learning between the companies involved (Hervas-Oliver \& AlborsGarrigós, 2009; McEvily \& Zaheer, 1999). Access to information, knowledge, and technology inside a cluster and other external resources enable the firms to be more competitive, especially in the exporting and international context (Prim, Amal, \& Carvalho, 2016). According to Tallman et al. (2004), the more companies share conditions and experiences, the greater the mutual absorptive capacity will be regarding the knowledge of the cluster. This perspective deserves particular acknowledgment and understanding, given that the density may also cause diseconomies in the agglomeration, in cases where there is greater competition among the agglomerated companies (McCann \& Folta, 2008).

The fact that companies are geographically close tends to increase not only the frequency of interactions within a cluster but also the effectiveness of knowledge exchanges through face-to-face contact interactions between them, which fuels trust and institutional cooperation rules (Arikan, 2009; Bathelt, Malmberg, \& Maskell, 2004). It is an environment in which managers and workers are able to discuss the specific problems of the context, overcoming ambiguities and uncertainties through direct observation and confrontation, facilitating the development of valuable expertise, which can be translated into differentiation strategies for products and innovation (Giuliani, 2013). The partners invest time, attention, and many resources in the development of relational routines, believing that the resulting knowledge can be effectively incorporated into company strategies (Arikan, 2009).

Relationship analysis seems to be even more necessary when studying the reality of developing countries, because the specialized literature suggests that their economies suffer from severe market failures and institutional 
weaknesses, making it necessary for companies to overcome these elements (Giuliani, 2013). For the aforementioned author, companies that have an interest in strengthening themselves in the face of international competition should cultivate different types of relationships that are capable of providing access to resources, reduce information asymmetries between companies, enable high bargaining power with market agents, increase power with the government, and allow for constant updating of their capacities.

Opportunism among network actors is supposed to be controlled through the effect of repeated transactions, reputation, and social norms that may be tied to the geographic location in particular or to the social group, and also the knowledge exchanged among network members (Gereffi, Humphrey, \& Sturgeon, 2005; Wegner, Bortolaso, \& Zonatto, 2016).

It is also possible that, over time, these relationships will wear out, and the knowledge derived from the links will not compensate for the continuous maintenance costs. This is when the companies go in search of new horizons to continue growing (Arikan, 2009). Bouncken and Kraus (2013) consider that despite the high risks of opportunism among co-opponents, companies form alliances to access and leverage valuable knowledge. Finally, although the networks of relationships are promising for their participants, their knowledge gains stem from the absorptive capacity of each company, which involves the ability to discover and exploit available knowledge (Chim-Miki \& Batista-Canino, 2017; Kogut, 2000; McEvily \& Zaheer, 1999; Tallman et al., 2004).

\section{Methodological Aspects}

The study followed the qualitative research approach (Lincoln \& Guba, 2000; Merriam, 1998), making it possible to develop an interpretative case study, containing a rich description of the studied phenomenon, while looking for patterns in the data and developing conceptual categories that make it possible to illustrate, confirm, or oppose theoretical assumptions (Merriam, 1998; Patton, 2002). Similar research strategies have been used by other studies on inter-organizational relationships (Larentis, Antonello, \& Slongo, 2018).

The study initially aimed to investigate fruit producers and exporters present in the São Francisco River Valley, but it was also necessary to consider the level of analysis of the cluster, in the understanding that clusters and geographically concentrated companies coevolve. Systems are so involved in local network dynamics that taking only one level as a unit of analysis would make the phenomenon narrow and simplified (HervasOliver \& Boix-Domenech, 2012; Ter Wal, 2013).

In order to choose the companies, the list of exporting companies made available by the Ministry of Development, Industry, and Foreign Trade, through the Secretariat of Foreign Trade (Secex), was first considered. This is complemented by a register of grape and mango exporters provided by the Ministry of Agriculture, Livestock, and Supply. From these lists, a network of contacts was drawn up in order to gain access to the business subjects of the research. In addition to contacting corporate executives, the understanding that companies and clusters coevolve gave rise to the need to seek access to a set of cluster actors who had important information for understanding the phenomenon.

Following the recommendations for building good qualitative research (Eisenhardt \& Graebner, 2007; Yin, 2016), multiple data sources were considered, but at the heart of this study was the semi-structured interview with executives from medium and large exporters and institutional and support industry actors. This process is better displayed in Figure 1, based on concepts of Larrinaga Villarreal (2017), Yin (2016), and Zhang and Shaw (2012), which comprises an overview of the research, covering its general design, units of analysis, data collection procedures, and iterative data analysis process.

Considering the reality of the period of data collection through interviews, it is estimated, 
based on the interviews obtained, that the volume produced by the companies participating in this study exceeded $50 \%$ of the total volume exported by the region. To complement the interview information, public and private documents were analyzed. Furthermore, secondary data on the region, especially academic documents developed within the context under study, added support to the analysis.

Table 1

\section{Research Technical Data}

\begin{tabular}{|c|c|c|c|c|}
\hline Research methodology & \multicolumn{2}{|c|}{ Qualitative case study } & & \\
\hline Geographical scope & \multicolumn{2}{|c|}{ Agricultural cluster in Brazil } & & \\
\hline Unit of analysis & \multicolumn{4}{|c|}{ Geographically concentrated companies in SFRV and their cluster, which co-evolve } \\
\hline $\begin{array}{l}\text { Methods of data } \\
\text { collection }\end{array}$ & \multicolumn{4}{|c|}{$\begin{array}{l}\text { At the heart of the study were semi-structured interviews, along with secondary data from public } \\
\text { and private documents }\end{array}$} \\
\hline & Why? & What? & How? & So? \\
\hline $\begin{array}{l}\text { Semi-structured } \\
\text { interviews } \\
\text { (July- } \\
\text { September/2014) }\end{array}$ & $\begin{array}{l}\text { To analyze how } \\
\text { horizontal relationship } \\
\text { resources collaborated } \\
\text { in the value creation } \\
\text { process of fruit } \\
\text { producing and } \\
\text { exporting companies } \\
\text { geographically } \\
\text { concentrated in the } \\
\text { São Francisco River } \\
\text { Valley. }\end{array}$ & $\begin{array}{l}13 \text { interviews were } \\
\text { conducted with executives } \\
\text { from } 9 \text { medium or large } \\
\text { table grape and mango } \\
\text { exporters from the } \\
\text { SFRV, and } 9 \text { interviews } \\
\text { were conducted with } \\
\text { institutional and support } \\
\text { industry actors. }\end{array}$ & $\begin{array}{l}\text { Different interview } \\
\text { scripts were used } \\
\text { for corporate and } \\
\text { institutional actors. } \\
\text { The average interview } \\
\text { time was } 53 \text { minutes, } \\
\text { totaling about } 1200 \\
\text { minutes of recording. }\end{array}$ & $\begin{array}{l}\text { Rich information } \\
\text { was obtained, which } \\
\text { was transcribed } \\
\text { and duly coded for } \\
\text { analysis. }\end{array}$ \\
\hline $\begin{array}{l}\text { Document } \\
\text { analysis } \\
\text { (2014 and 2018) }\end{array}$ & $\begin{array}{l}\text { To complement } \\
\text { the interview } \\
\text { information and } \\
\text { identify relationship } \\
\text { patterns and ways to } \\
\text { create value for the } \\
\text { businesses and cluster. }\end{array}$ & $\begin{array}{l}\text { Constitutive and } \\
\text { informative documents of } \\
\text { companies, associations, } \\
\text { cooperatives, and support } \\
\text { institutions, } \\
\text { obtained predominantly in } \\
2014 \text {. Secondary } \\
\text { articles on the } \\
\text { development of the } \\
\text { sector were also used. }\end{array}$ & $\begin{array}{l}\text { Most of the } \\
\text { documents provided } \\
\text { were printed by } \\
\text { organizations or } \\
\text { available online. } \\
\text { Regarding the } \\
\text { online documents, } \\
\text { the content was } \\
\text { reinforced in } 2018 \text {. }\end{array}$ & $\begin{array}{l}\text { The information } \\
\text { was coded for the } \\
\text { analysis. }\end{array}$ \\
\hline Data analysis & \multicolumn{4}{|c|}{$\begin{array}{l}\text { The data were examined, categorized, and combined to find evidence. This research opted to } \\
\text { develop a content analysis (Bardin, 1977) with the support of the qualitative software Atlas.ti. }\end{array}$} \\
\hline $\begin{array}{l}\text { Rigor/Quality of the } \\
\text { research }\end{array}$ & \multicolumn{4}{|c|}{$\begin{array}{l}\text { It involves an in-depth understanding of the field and triangulation of the data. The research can } \\
\text { be replicated in other contexts involving the geographical concentration of companies. }\end{array}$} \\
\hline
\end{tabular}

Note. The table shows a methodological overview prepared by the authors.

The theoretical and methodological triangulation required constant reflection by the researchers, with saturation occurring as the constructions became more robust and stable. The coding process was marked by comings and goings, as an iterative process that would help adjust the categories of analysis and establish a more elaborate research design (Flick, 2009; Gioia, Corley, \& Hamilton, 2013; Zhang \& Wildemuth, 2016). Scientific rigor and analytical depth were present in the data analysis, probably the most problematic phase in the development 
of a qualitative case study (Flick, 2009; Patton, 2002). This research opted to develop a content analysis, a refined technique that requires a lot of dedication, patience, and time from the researcher, who should use intuition, imagination, and creativity, especially in when defining the categories of analysis (Mozzato \& Grzybovsky, 2011). The analysis carried out followed the guidelines of Bardin (1977), covering the preanalysis stage, material exploration and treatment of results, inference, and interpretation, with the support of the qualitative software Atlas.ti version 7.5.5, using the guide developed by Friese (2012).

Atlas.ti enabled the systematization of categories and subcategories, which were illustrated through conceptual networks. The numbering appears next to the quotations (excerpts encoded in the analysis), for example QU: 25: 29 represents the 29th excerpt encoded in P-Doc 25. The codes show numbering in brackets, for example $\{22-2\}$, which indicates that the code was used 22 times and has 2 links with other codes. Occasionally the signal $(\sim)$ can be found, which represents the existence of a comment.

Finally, the theoretical basis of this research is generic, and its premises can be used for other contexts involving the geographical concentration of companies. The richness of the description and analysis of the empirical data also enable researchers to make applications in similar contexts and even carry out quantitative applications based on the findings presented.

\section{Horizontal Relationship Resources of the San Francisco River Valley}

\section{Horizontal Relationship Resources are} derived from the bonds established between the local actors in a cluster, representing the collective gains established by multiple and frequent collaborative relationships. Regarding these, the analysis of the data in this research allowed the identification of 11 categories, which are shown in Figure 1.

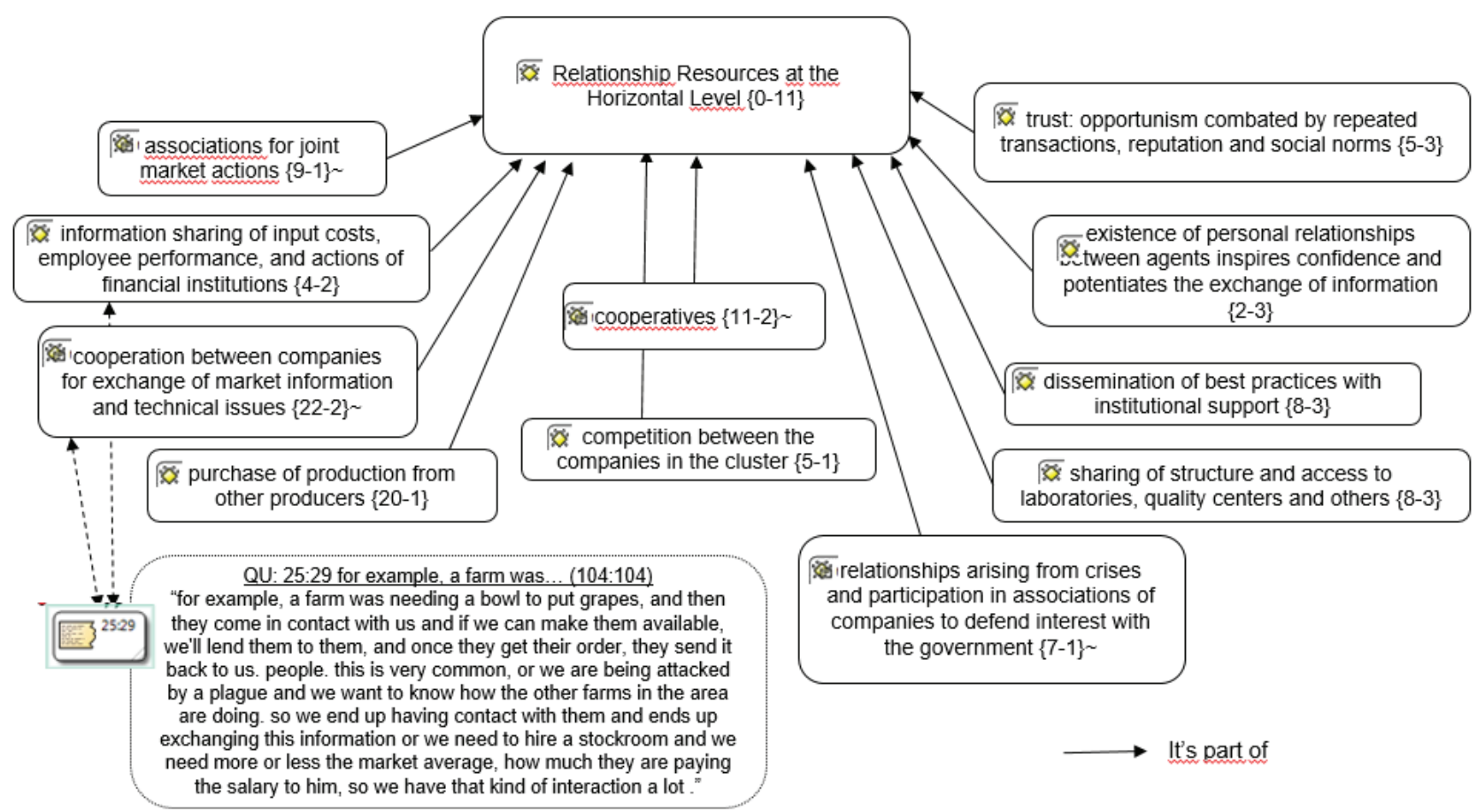

Figure 1. Horizontal Relationship Resources of the San Francisco River Valley 
The relationships established between the companies of the SFRV were fundamental to the initial exporting of fruits from the region, especially grapes. Between the 1980s and 1990s, the relationships between producers focused on export processes led to the formation of the Brazilian Grape Marketing Board (BGMB), which later became the Brazilian Grape Marketing Association (BGMA). This was an association of exporters headed by a branch of the Cotia Agricultural Cooperative (CAC) in Juazeiro, Bahia. CAC began operations between the 1920s and 1930s in the state of São Paulo, acting as one of the main cooperatives in Brazil during the last century. It was attracted to the Sáo Francisco River Valley region to work with grapes and played an important role in structuring export fruit operations in the region. In the 1990s it filed for bankruptcy, and its operations in the Valley were taken over by the Juazeiro Agricultural Cooperative (JAC). JAC ended up growing many companies that had an interest in exporting, had know-how regarding cooperation, and also had access to an international market in the Netherlands, this being the initial knowledge that was fundamental for other producers to be able to perceive the international market as an opportunity. The BGMA also had institutional support, which was provided through Valexport's actions:

The company was born from this thinking, at the time we had the BGMA here, an association of exporters. We participated for a year. It was an association that exported the members' fruits. At that time they had an office in the Netherlands and we would send the fruits there. Valexport was very important. There was a Brazilian agent who lived there and represented us, making the sales. After 2 or 3 years, we realized that the best thing was to do this marketing with the brand itself, to be independent, which was in 1996 or 1998 (CEO of GVS - 32: 2).

After the initial experiences, recognition of the mode of operation and condition of sale by consignment led some of the exporting farms to seek independent channels, and this also happened with Queiroz Galvão Alimentos: "Participation on the board served to acquire knowledge of the export processes, then we chose to pursue a separate path, avoiding sales by consignment" (CEO of QueirozGalvão - 15:32). Considering this evidence, and also based on the documents analyzed, it was noted that the participation and leadership of large companies with valuable production and commercial experience and the involvement of new players, together with the institutional support, was able to drive the development of the cluster and its access to the international market.

The fruit producers and exporters of the San Francisco Valley see in the relationships between them opportunities to strengthen themselves against international competitors. In accordance with Porter (1998), a low barrier to information protection was perceived regarding input costs, employee performance, the actions of financial institutions, and especially information related to the market and technical aspects of production.

Unlike the industrial sector, where there are many secrets, here it is totally open. You can talk to agronomists from large farms and small producers and exchange ideas. There's a network of consultants who promote semiannual meetings of producers, precisely seeking integration and the exchange of information (CEO of COANA - 22:61).

Also following the paths of the specialized literature (Dyer \& Sight, 1998; McEvily \& Zaheer, 1999; Giuliani, 2013; Ter Wal, 2013; Zen et al., 2014), the relationships between SFRV producers have presented themselves as critical resources in value creation. These links were favored by the dependence found among the producers, "if it goes well, but another 5 go badly, it is possible that in the future it too will go badly" (SebraeBA_InstitutionalActor - 5:32).

Why are we not competitive? Because the market wants more than just mine. 
10 acres for a buyer is very little out there, so the export is too little. He (the buyer) wants a lot, he wants 200 hectares, 100 hectares, he wants a lot ... So you alone can't supply him, you have to join with someone to be able to fulfill an order from there (SebraePE_ InstitutionalActor - 6:35).

Also reinforced by the analysis of the internal documents of some companies and institutions, it was noted that the small producer depends on the structure of the big producer to access the international market, and in turn, the big producer needs the small one to achieve the volume desired by its client. These links between different levels of producers are complex and generate mutual dependence among them, it being understood that the more intense this is the greater the absorptive capacity of the companies within the cluster (Tallman et al., 2004). The following comment supports this argument:

Sometimes we pick up from some other producer too, when there is a shortage of product. For example, this year the market has asked for a lot of fruit. If you have a small producer that we know, we trust, because in the first place it has to be certified, if it has not been certified, people cannot buy it, so we end up buying and exporting it, and even in the domestic market, sometimes we buy fruit from third parties to make up our shortage (CEO of CoopexVale - 24:38).

One aspect of ours is that we buy from many other producers. We produce $50 \%$ of our volume and the rest comes from about 30 other producers (CEO of GVS - 32:7).

Apart from our own production, we buy a lot of fruit here in the region, from other producers. I would say we have bought between 30 and $40 \%$ of our total volume from other producers. We're an important partner of many mango producers here in the San Francisco Valley (CEO of UpaAgrícola $-18: 8$ ).

We do not buy fruit from third parties to market, we buy for the industry. We have the idea of creating a stronger bond for coconut producers and producers of acerola, but without financing, only creating a greater commitment that we will purchase, and to sell some of it (CEO of QueirozGalvão - 15:54).

Dependence on the production of other companies within the cluster raises the need for cooperation to coexist in harmony with the competition, ensuring the conditions for coopetition among SFRV producers. This is the expected behavior of firms within a cluster (Brandenburger \& Nalebuff, 1996; Chim-Miki \& Batista-Canino, 2017).

The links established in the purchase relationships for small fruit production by the large SFRV producers were often mediated by advanced payment to finance production, implying a closer linkage. In some cases, the purchasers were able to determine how the supplier was working as a way to achieve the expected quality. In addition, some respondents indicated that although the cluster environment provides interactions that feed the trust relationships (Arikan, 2009; Bathelt et al., 2004), it is possible that opportunistic situations may occur, such as this one:

In the past, we offered some advances to help the producer close the deal, but it didn't work, because the producer ends up wanting to "find a clever way" and produces and sells to someone else and pays whenever. So we understand that advance payment to the producer doesn't work, because the producer has the psychology that the money he received is money he is in no hurry to pay (CEO of UpaAgrícola - 18:44).

The issue of opportunism is tackled by SFRV companies through repeated transactions, reputation, and social norms of the locality, which is consistent with the approach of Gereffi et al. (2005). Gradually, many of the relationships continue to be reinforced through successful experiences between the links and the possibility of medium- or long-term relationships tends to offset the immediacy of the gains: "I have partners 
that if I say I'll buy a pound of mango for $\mathrm{R} \$ 1.30$, they won't sell to that guy for $\mathrm{R} \$ 2.00$, because they know that if that guy buys a truck, in 10 days he'll disappear and there'll be no relationship" (Commercial Director of Argofruta - 21:16). In other relationships, when one party still does not have the necessary confidence in another, the commitments are mediated by contractual agreements: "these contracts [it was shown to the interviewers] impose some clauses with fines, and failure to comply with them in some situations leads to payment of $30 \%$ of the amount that was advanced" (Commercial Director of GVS - 31:19).

Some attempts were made in the region for Associations to discuss the collective interests of producers, such as the Petrolina Chamber of Fruticulture and the Juazeiro Fruit Institute. Both are formed of producers from the region who meet frequently and are most concerned about financial demands. The producers' biggest problems are related to out-of-season rains, which may impair the expected quality of the fruits, and crises in the economy, which have an impact on the financial management of the companies.

The producer, in general, thinks that he does not need to participate in Associations. It only joins when there is a catastrophe... financial need! Then everyone searches for associations to make the political movement (GrapesConsultant - 3:30).

Our role is to raise the main problems of the region, linked to fruit growing, the chain of fruit growing, and seek possible solutions. And in this context, we managed, for example, to renegotiate the debts of Valley producers after the 2008 crisis, in several ways. The last one was in 2010 in National Monetary Council / BACEN resolution 38/99, which is the only resolution there is for the Valley, and nominally cites the four cities of Bahia and the four cities of Pernambuco that could renegotiate their indebtedness (Juazeiro Fruit Institute_Actor - 11:3).

More recently, there has been an observed development of associations between some entrepreneurs to carry out closed contracts for importing or developing exclusive varieties: "I'll have an extremely competitive variety that only a small group that made the contract could explore. This I think can be the big difference in the future" (GrapesConsultant - 3:20). The relationships between companies within the cluster favored the flow of knowledge and the adoption of innovations as a path to competitive differentials, which is consistent with the studies by Hervas-Oliver and Albors-Garrigos (2009) and Bahlmann and Huysman (2008).

Among the SFRV producers, competition is intensified when the export window is shortened, or when market speculation on the part of the producers leads to a concentration in export volume in the final period of the sales window. The reports obtained point to a lack of coordinated actions in terms of the region's exports so that strategies are followed by each company. For the respondents, governance actions could enable more robust gains for the producers.

When the market, for example in Europe, is not stable, some big farms here in the Valley hold grape sales to improve the price, suddenly there is congestion and we will lower the price. So, really the competition is there in the sales, there where the grape is placed on the market (CEO of Labrunier - 13:22).

The disadvantage of Brazil is, first, the lack of organization of the producers. Maybe, if we had a union, were more organized at the point to getting together, getting together, demanding from the market, from the government, so that we had a certain guarantee, maybe that would work better. It's what I said before, we here have a lot of individual thinking, so with that, you're done, everyone who wants to get rid of yours and the neighbor who finds a way... (Commercial Director of GVS - 31:25).

In this aspect, the associations that bring together producers and exporters in the region seem to have been unable to make sufficient progress, demonstrating that the 
individual strategies of these companies may end up overriding the cooperation links that could generate collective benefits; that is, the relationships links are limited by the strategic interests of individual companies. These aspects, in which competition among firms outweighs the expected cooperation benefits of the cluster, may point to other diseconomies of scale of the clustered companies, in addition to those already pointed out by McCann and Folta (2008).

Some of the companies interviewed are cooperatives, representing the interests of small and medium producers that unite in search of gaining competitiveness in the face of big producers and obtaining facilities to access the international commercialization channels.

Links between entrepreneurs are most often seen in cooperatives, where various groups come together to become strong in buying inputs and selling their fruits, especially for export. For example, we have Coana, Coopexvale, Coopexfruit, CAJ, various organized and even informal groups. Even the big ones get together, too. So there are several groups, for example Coopexvale, which, including the whole cooperative, has more than 200 hectares. They come together to buy boxes, packaging, get together for a need. Now, what were those needs? Marketing, storage, because there has to be a conditioned room. The investment for anyone who has 10 hectares to build a cold chamber to cool a fruit is very high, not worth it, understand? In the case of the cooperative, it does everything, it does the marketing, it makes the contract, it closes the deal, it makes the estimate, the whole story, and from the price of the deal it already takes a percentage of it, you see? (SebraePE_ InstitutionalActor - 6:36)

The cooperative enables the sharing of physical resources, which would not be possible individually (such as conditioned rooms to keep the fruit at the right temperature for export), and the organization necessary for developing international business. "The cooperative companies continue to have independence in conducting their business and also in the national negotiations" (CEO of COANA - 22:20), that is, the cooperative acts as a necessary structure for the export activities of these companies. The participation of small companies in cooperatives has allowed access to innovations, improvements in the productive process and enhanced international commercialization.

The relationships between the companies in associations or cooperatives in the SFRV have also allowed access to relevant actors in the global value chain for fresh fruits. Among these, it is worth highlighting the reality perceived in internal COANA documents, which, as a cooperative, enables valuable relationships with International Fruit Genetics (IFG) and Sun World Innovation, two of the world's largest fruitbreeding operations, with a broad-based portfolio of plant patents and trademarks and investments in agriculture technology.

Relationships between companies were also identified, involving an institutional partnership between some companies of the Valley to develop experiments in their productive areas, and the results were disseminated by the community of producers in the region. The institutions also enable the sharing of physical structures among companies in the region, integrating entrepreneurs and providing a more intense flow of knowledge.

The evidence of relationships between SFRV companies presented here reinforces the existence of constant, often unstructured and fragmented knowledge exchange among the companies, as pointed out by Malmberg and Maskell (2010). The local reality also suggested that these relationships tend to be valuable and lasting insofar as individual advantages are perceived in the short term.

\section{Conclusions}

This paper expands the empirical evidence on organizational relationships by presenting a study of a Brazilian agricultural cluster. The results revealed particular patterns of collaboration that indicate conditions and contributions derived 
from the links established among the firms within the cluster, and highlight the companies' strategies to create value.

The flows of knowledge or resources between the companies were based on what is meant by relationship resources at the horizontal level, manifested by several paths between the companies of the San Francisco River Valley, including the constitution of the joint international marketing board, relationships established for purchasing from other producers, cooperation between companies for exchanging technical and market information, and the setting up of cooperatives, among others.

The results showed that the participation and leadership of large companies with valuable production and commercial experience, the relationships established with the small producers, and the relevant institutional support were able to drive the development of the cluster and its access to the international market.

Dependence on the production of other companies within the cluster raises the need for cooperation in order to coexist in harmony with the competition, thus ensuring the conditions for coopetition among the SFRV producers. The greater the intensity of these relationships, the greater the absorptive capacity of each company involved will be, which can be illustrated by the case of cooperatives, whose exports are carried out jointly by the collective, and which would not be possible for each company individually. The participation of small companies in cooperatives enabled access to innovations, improvements in the productive process, and strengthened international commercialization. In particular, the results indicated that companies tend to perceive and absorb the relationship resources at the horizontal level more intensely, given the insignificance of the producers offering in comparison to what the market demands. Significant volumes, especially those meant for the international market, bring companies closer in terms of production protocols and joint business practices. These aspects favor collaboration in an essentially competitive environment.
It is important to emphasize the existence of other components of the cluster whose actions involved strengthening cooperation links, such as technical consultants and local institutions, especially research ones. These agents showed strategic importance throughout the evolution of the cluster, and were important in the process of structuring the current and future links between companies.

In order to be able to generalize the results more and as suggestions for future research, there needs to be a greater emphasis on how relationships between firms strengthen opportunities for knowledge spillovers to enable innovation cycles; the relationships between cluster companies and actors in the global value chain could be investigated; and there should be studies related to other knowledge derived from the presence of companies in a cluster environment.

In practical terms, it is recognized that although export agribusiness in the San Francisco Valley does not represent a large portion of Brazil's international trade, its development represents a valuable source of economic and social development for a region lacking business and government alternatives. This paper is of interest to both researchers and policymakers who are interested in the dynamic sources of competitive advantages of clusters and their firms.

\section{References}

Arikan, A. T. (2009). Interfirm knowledge exchanges and the knowledge creation capability of clusters. Academy of Management Review, 34(4), 658-676.

Bahlmann, M. D., \& Huysman, M. H. (2008). The emergence of a knowledge-based view of clusters and its implications for cluster governance.

The Information Society, 24(5), 304-318.

Bardin, L. (1977). L'analyse de contenu, [Content Analysis]. Paris: Presses Universitaries de France. 
Barney, J. (1991). Firm resources and sustained competitive advantage. Journal of Management, 17(1), 99-120.

Bathelt, H., Malmberg, A., \& Maskell, P. (2004). Clusters and Knowledge: Local Buzz, Global Pipelines and the Process of Knowledge Creation. Progress in Human Geography, 28, pp. 31-56.

Bengtsson, M., Raza-Ullah, T., \& Vanyushyn, V. (2016). The coopetition paradox and tension: The moderating role of coopetition capability. Industrial Marketing Management, 53, 19-30.

Bouncken, R. B., \& Kraus, S. (2013). Innovation in knowledge-intensive industries: The doubleedged sword of coopetition. Journal of Business Research, 66(10), 2060-2070.

Brandenburger, A., \& Nalebuff, B. (1996). Coopetition: A revolutionary mindset that combines competition and cooperation in the marketplace: The game theory strategy that's changing the game of business. New York: Ediçóes Harper-Collins.

Chim-Miki, A. F., \& Batista-Canino, R. M. (2017). Partnering based on coopetition in the interorganizational networks of tourism: a comparison between Curitiba and Foz do Iguaçu, Brazil. Revista Brasileira de Gestão de Negócios, 19(64), 219-235.

Dierickx, I., \& Cool, K. (1989). Asset stock accumulation and sustainability of competitive advantage. Management Science, 35(12), 15041511 .

Dyer, J. H., \& Singh, H. (1998). The relational view: Cooperative strategy and source of interorganizational competitive advantage. Academy of Management Review, 23(4), 660-667.

Eisenhardt, K. M., \& Graebner, M. E. (2007). Theory building from cases: Opportunities and challenges. The Academy of Management Journal, 50(1), 25-32.
Eisingerich, A. B., Bell, S. J., \& Tracey, P. (2010). How can clusters sustain performance? The role of network strength, network openness, and environmental uncertainty. Research Policy, 39(2), 239-253.

Flick, U. (2009). Desenho da pesquisa qualitativa. Porto Alegre: Artmed.

Friese, S. (2012). Qualitative data analysis with ATLAS.ti. Los Angeles: Sage.

Gereffi, G., Humphrey, J., \& Sturgeon, T. (2005). The governance of global value chains. Review of International Political Economy, 12(1), 78-104.

Gioia, D. A., Corley, K. G., \& Hamilton, A. L. (2013). Seeking qualitative rigor in inductive research: Notes on the Gioia methodology. Organizational research methods, 16(1), 15-31.

Giuliani, E. (2013). Network dynamics in regional clusters: Evidence from Chile. Research Policy, 42(8), 1406-1419.

Giuliani, E., \& Bell, M. (2005). The microdeterminants of meso-level learning and innovation: Evidence from a Chilean wine cluster. Research Policy, 34(1), 47-68.

Hervas-Oliver, J. L., \& Albors-Garrigos, J. (2007). Do clusters capabilities matter? Empirical evidence in European clusters. Entrepreneurship and Regional Development, 19(2), 113-136.

Hervas-Oliver, J. L., \& Albors-Garrigos, J. (2009). The role of the firm's internal and relational capabilities in clusters: When distance and embeddedness are not enough to explain innovation. Journal of Economic Geography, 9(2), 263-283, 2009.

Hervas-Oliver, J.L., \& Boix-Domenech, R. (2012). The economic geography of the mesoglobal spaces: Integrating multinationals and clusters at the local-global level, European planning studies, 
Routledge, pp. 1-17. Retrieved from https://www. tandfonline.com/doi/abs/10.1080/09654313.20 13.733853

Hervas-Oliver, J. L., Albors-Garrigos, J., Miguel, B., de, \& Hidalgo, A. (2012). The role of a firm's absorptive capacity and the technology transfer process in clusters: How effective are technology centres in low-tech clusters?. Entrepreneurship \& Regional Development, 24(7-8), 523-559.

Kogut, B. (2000). The Network as knowledge: Generative rules and the emergence of structure. Strategic Management Journal, 21, 405-425.

Larentis, F., Antonello, C. S., \& Slongo, L. A. (2018). Organizational culture and relationship marketing: An interorganizational perspective. Revista Brasileira de Gestão de Negócios, 20(1), 37-56.

Larrinaga Villarreal, O. (2017). Is it desirable, necessary and possible to perform research using case studies?. Cuadernos de Gestión, 17(1), 147172.

Lastres, H. M. M., Cassiolato, J. E., \& Campos, R. (2006). Arranjos e sistemas produtivos e inovativos locais: Vantagens do enfoque. In H. M. M. Lastres \& J. E. Cassiolato. Estratégias para o desenvolvimento: Um enfoque sobre Arranjos Produtivos Locais do Norte, Nordeste e Centro-Oeste Brasileiros (pp. 13-28). Rio de Janeiro: E-papers.

Lazzeretti, L., Sedita, S.R., \& Caloffi (2013). Founders and disseminators of cluster research. Journal of Economic Geography, 14(1), 1-23.

Lincoln, Y. S., \& Guba, E. G. (2000). Paradigmatic controversies, contradictions, and emerging confluences. In N. K. Denzin, \& Y. S. Lincoln (Eds). Handbook of qualitative research (2nd ed., pp. 163-188). Thousand Oaks: SAGE.

Malmberg, A., \& Maskell, P. (2002). The elusive concept of localization economies - Towards a knowledge-based theory of spacial clustering. Environment and Planning, A 34(3), 429-449.
Malmberg, A., \& Maskell, P. (2010). An Evolutionary Approach to Localized Learning and Spatial Clustering. In R. Boschma, R. Martin. The Handbook of Evolutionary Economy Geography (Cap. 18). Northampton, MA (USA): Edward Elgar.

Martin, R., \& Sunley, P. (2003). Deconstructing clusters: Chaotic concept or policy panacea? Journal of Economic Geography, 3(1), 5-35.

McCann, B., \& Folta, T. (2008). Location matters: Where we have been and where we might go in agglomeration research. Journal of Management, 34(3), 532-565.

McEvily, B., \& Zaheer, A. (1999). Bridging ties: A source of firms heterogeity in competitive capabilities. Strategic Management Journal, 20(12), 1133-1156.

Merriam, S. B. (1998). Qualitative research and case study applications in education. San Francisco: Jossey-Bass.

Molina-Morales, X., \& Martinez-Fernandez, T. (2004). How much difference is there between industrial district firms? A net value creation approach. Research Policy, 33(3), 473- 486.

Mozzato, A. R., \& Grzybovski, D. (2011). Análise de conteúdo como técnica de análise de dados qualitativos no campo da administração: potencial e desafios. Revista de Administração Contemporânea, 15(4), 731-747.

Patton, M. (2002). Qualitative research and evaluation methods (3rd ed.). Thousand Oaks:Sage.

Porter, M. E. (1991). Towards a Dynamic Theory of Strategy. Strategic Management Journal, 12, 95-117.

Porter, M. E. (1998). Clusters and the New Economics of Competition. Harvard Business Review, 76(6), 79-91.

Porter, M. E. (2000). Location, competition, and economic development: Local clusters in a 
global economy. Economic Development Quarterly, 14(1), 15-34.

Prim, A. L., Amal, M., \& Carvalho, L. (2016). Regional cluster, innovation and export performance: An empirical study. Brazilian Administration Review, 13(2), art. 5. doi: https:// dx.doi.org/10.1590/1807-7692bar2016160028

Rigby, D. L., \& Brown, M. W. (2015). Who Benefits from Agglomeration?, Regional Studies, 49(1), 128-43. doi: 10.1080/00343404.2012.753141

Suzigan, W., Garcia, R., \& Furtado, J. (2005). Sistemas locais de produção/inovação: Metodologia para identificação, estudos de casos e sugestōes de políticas. In C.C. Diniz \& M.B. Lemos (Orgs.), Economia e território (287-320). Belo Horizonte: Ed. UFMG.

Tallman, S., Jenkins, M., Henry, N., \& Pinch, S. (2004). Knowledge, clusters, and competitive advantage. The Academy of Management Review, 29(2), 258-271.

Ter Wal, A. L. J. (2013). Cluster Emergence and Network Evolution: A Longitudinal Analysis of the Inventor Network in Sophia-Antipolis. Regional Studies, 47(5), 651-668.

Verschoore, J.R., Wegner, D. \& Balestrin, A. (2015). The evolution of collaborative practices in small-firm networks: A qualitative analysis of four Brazilian cases, International Journal Management Practice, 8(2), 152-168.

Wegner, D., Bortolaso, I., \& Zonatto, P. (2016). Small-Firm networks and strategies for consolidation: Evidence from the Brazilian context. Review of Business Management, 18(62), 525-544. doi:https://doi.org/10.7819/rbgn. v18i62.2301

Yin, R.K. (2016). Qualitative Research from Start to Finish (2nd ed.). New York: Guilford Press.

Zen, A. C., Fensterseifer, J. E., \& Prévot, F. (2014). O impacto dos recursos do desempenho exportador de empresas pertencentes a clusters: Um estudo no setor vitivinícola francês. Revista Brasileira de Gestão de Negócios, 16(52), 374-391.

Zhang, Y., \& Shaw, J. D. (2012). Publishing in AMJ-Part 5: Crafting the methods and results. Academy of Management Journal, 55(1), 8-12.

Zhang, Y., \& Wildemuth, B. M. (2016). Qualitative analysis of content. In B. M. Wildemuth (Eds.), Applications of social research methods to questions in information and library science (2nd ed., Cap. 32, pp. 318 -329). Santa Barbara: Libraries 


\section{Supporting Agencies:}

Capes BEX 5352/14-2

CNPq - Chamada Universal 2016, processo 431471/2016-9

MINISTERIO DE CIENCIA, INNOVACIÓN Y UNIVERSIDADES, RTI2018-095739-B-100

\section{About the Authors:}

1. Vinicius Farias Moreira, PhD in Management, Federal University of Pernambuco, Postgraduate Program in Management, Recife, Pernambuco, Brazil. E-mail: vinicius.moreira@ufcg.edu.br, viniciusfmoreira@

yahoo.com.br

ORCIID

(iD) 0000-0002-4473-8766

2. Walter Fernando Araujo de Moraes, $\mathrm{PhD}$ in Management, University of Manchester Institute of Science and Technology, UMIST, England. E-mail:wfam1950@gmail.com

ORCID

(iD) 0000-0003-4582-0910

3. Jose Luis Hervas-Oliver, PhD in Management, Universitat Politecnica de Valencia, Valencia, Spain.

E-mail: jose.hervas@omp.upv.es

ORCIID

(iD) 0000-0001-6438-5497

4. Samuely Bezerra Barbosa Laurentino, master student at University of São Paulo, School of Economics, Business and Accounting, São Paulo, Brazil. E-mail: samuely@usp.br

ORCID

(iD)0000-0003-3381-7570

\section{Contribution of each author}

Each author should take responsibility for at least one component of the paper. If the article is approved for publication, the authors should indicate in the diagram below, what was the contribution of each.

\begin{tabular}{lcccc}
\hline Contribution & $\begin{array}{c}\text { Vinicius } \\
\text { Farias } \\
\text { Moreira }\end{array}$ & $\begin{array}{c}\text { Walter Fernando } \\
\text { Araújo de Moraes }\end{array}$ & $\begin{array}{c}\text { Jose Luis } \\
\text { Hervas-Oliver }\end{array}$ & $\begin{array}{c}\text { Samuely } \\
\text { Bezerra Barbosa } \\
\text { Laurentino }\end{array}$ \\
\hline 1. Definition of research problem & $\sqrt{ }$ & $\sqrt{ }$ & $\sqrt{ }$ \\
2. Development of hypotheses or research questions & $\sqrt{ }$ & $\sqrt{ }$ & $\sqrt{ }$ \\
(empirical studies) & $\sqrt{ }$ & $\sqrt{ }$ & $\sqrt{ }$ \\
3. Development of theoretical propositions (theoretical work) & $\sqrt{ }$ & $\sqrt{ }$ \\
4. Theoretical foundation/Literature review & $\sqrt{ }$ & $\sqrt{ }$ & \\
5. Definition of methodological procedures & $\sqrt{ }$ & $\sqrt{ }$ & \\
6. Data collection & $\sqrt{ }$ & $\sqrt{ }$ & \\
7. Use of Atlas.ti software & $\sqrt{ }$ & $\sqrt{ }$ \\
8. Analysis and interpretation of data & $\sqrt{ }$ & & \\
9. Critical revision of the manuscript & $\sqrt{ }$ & & \\
10. Manuscript writing & & & \\
11. Other (please specify which) &
\end{tabular}

This information will be available in publications as an end notal in accordance with the criteria, policies and procedures for admission and permanence of scientific journals in SciELO Brazil Collection.

\section{Erratum}

Where was written:

“Review of Business Management, São Paulo, v.21, n.4, p.706-721, oct/dec. 2019”

Now read:

“Rev. Bras. Gest. Neg. São Paulo v.21, Special Issue. 2019 p. 706-721” 